\title{
Accommodating the Needs of iConsumers: Making Sure They Get Their Money's Worth of Digital Entertainment
}

\author{
Lucie Guibault
}

Received: 19 June 2008 / Accepted: 9 October 2008 /

Published online: 31 October 2008

(C) The Author(s) 2008. This article is published with open access at Springerlink.com

\begin{abstract}
The current methods of distributing music and film on the mass-market, either off-line or on-line, raise two types of consumer protection issues. First, consumers are not always in a position to know what they can and cannot do with their digital hardware and content. A lack of proper information and the ensuing failure of the products to meet the consumer's expectations inevitably leads to discontent. In addition, as weaker party in the transaction, consumers have often no other choice but to accept or refuse the restrictive terms of use, even if these could be regarded as unfair. This paper examines whether European law is amenable to accommodate the iConsumer's needs, and if so, in what form.
\end{abstract}

Keywords Copyright · Technological protection measures · Licensing terms · Transparency · Fairness of contract terms

According to the latest figures released by the International Federation for the Phonographic Industry (IFPI) in January 2008, global digital music sales totalled an estimated US\$3 billion in 2007 , which indicates a rough increase of $40 \%$ from 2006 . The growing availability of repertoire and the spread of portable devices have helped drive music demand to an all time high. IFPI reports that there are now more than 500 licensed online music sites worldwide, offering over six million tracks, and that record labels are continuing to digitise their back catalogue. Despite these positive figures, IFPI concedes, however, that while interoperability has long been a key goal of the record industry, some major technology providers have been unwilling to participate in the development of technological solutions enabling fully interoperable Digital Rights Management (DRM) systems. Faced with this lack of progress, the major record labels decided to offer non-DRM download services, either permanently or as part of a trial period to supplement their existing offerings. ${ }^{1}$

\footnotetext{
${ }^{1}$ International Federation of Phonographic Industry (2008), Digital Music Report 2008-Summary, http:// www.ifpi.com/content/library/DMR2008-summary.pdf

L. Guibault $(\bowtie)$

Institute for Information Law, University of Amsterdam,

Rokin 84, 1012 KX Amsterdam, The Netherlands

e-mail: L.Guibault@uva.nl
} 
The announcement of the industry's move away from DRM and technological protection measures (TPM) came as music to the ears of consumers of legal digital products, whether off-line or on-line. Complaints against the upsetting and unexpected effects of TPMs were indeed not uncommon, ranging from the incapacity to play a piece of music on a normal consumer electronic equipment (such as a computer or a car radio), the incompatibility between files and devices, the impossibility to port a file from one format to another, and even to the damaging effect of TPMs on consumer devices. The music industry had in fact no choice but to react to these complaints, for the consequence of inaction would have been to push honest consumers towards the peer-to-peer file sharing of illegal material.

While TPMs may be loosing some ground, they have not yet entirely disappeared, however. They still cause frustration among consumers of digital music products and services (Helberger 2005, p. 2). Moreover, the industry's decision to gradually withdraw from the application of TPMs seems to be independent from that of using restrictive licensing conditions. A survey shows that even in the case of TPM-free music downloads, the terms of use attached to them usually purport to restrict the consumers' scope of action with respect to the songs they buy (Guibault et al. 2007, p. 139). And indeed, such conditions of use are often more restrictive than permitted by copyright law. Even if to our knowledge, no consumer has yet been sued for copyright infringement on the basis of these licensing conditions, the sustained practice of affixing such restrictive terms to digital music downloads is disquieting. In the long term, it may have a serious chilling effect on what would otherwise constitute a lawful use of a copyright protected work. It is also not excluded that, as a result of technological, economic, or social change, the music industry modify its attitude towards individual consumers who disregard the conditions of use and start instituting proceedings for infringement.

The current methods of distributing copyright protected music on the mass-market, either off-line or on-line, raise a number of concerns from the consumer's perspective, ranging from the transparency of use conditions, to the fairness in contracting, the remedies in case of insufficient information or unfair terms and the treatment of complaints. Indeed, consumers are not always in a position to know what they can and cannot do with their digital hardware and music content. A lack of proper information about the playability of a file or device and the ensuing failure of the products to meet the consumer's expectations inevitably lead to discontent. In addition, as weaker party in the transaction, consumers have often no other choice but to accept or refuse the restrictive terms of use, even if these could be considered unfair. The question is therefore whether the law is amenable to accommodate the consumer's needs, and if so, how.

This paper is divided into three sections. The first section considers the question of whether the music provider can be compelled by law to provide sufficient information regarding the application of TPMs and their effect on the usability of the product. In the following section, the use of restrictive licensing terms is put to the test, by examining the validity of such terms under copyright law and consumer protection law. This brief survey reveals that with respect to both issues, the European legislation could be adapted to take better account of the consumers' interests. In the third section, the type of legislative action that would be better suited to restore the balance of interests between rights owners and consumers is discussed.

It is important to stress, at the outset, that the recently coined concept of "iConsumer" is actually broader than the usual consumer as defined in Community legislation, since it encompasses not only a 'natural person who is acting for purposes which are outside his trade, business or profession', but all users of online information services. For the purposes of this article, however, we consider the iConsumer from a more narrow perspective, as the individual consumer of digital music and video products and services. 
These consumers mainly want to be able to make a private copy of their music or video's. The fact is, however, that European copyright law, in particular Directive 2001/29/ EC on the harmonization of copyright and related rights in the information society ${ }^{2}$, is not designed to address these consumer concerns. The primary purpose of this body of law is to protect the rights holder's interest. Hence, the vast majority of limitations on copyright, often erroneously referred to as 'fair use', ${ }^{3}$ are optional and are not intended to cater to the consumer's needs of transparency and fairness. This remark also applies to the private copy exemption of article 5(2)b) of Directive 2001/29/EC, which has not been implemented in every Member States, leaving consumers in the United Kingdom and Ireland without the right to make a private copy, except for time shifting purposes.

\section{Obligation to Inform}

The sale of music CDs and DVDs equipped with anti-copy mechanisms that prevent consumers from making a copy for time or place shifting purposes or that limit the playability of the support on different devices gave rise to a number of legal disputes in France. $^{4}$ In a series of cases brought before the courts in Paris, the French consumer protection association, UFC Que Choisir, argued successfully that the sale of a DVD protected by an anti-copy device without indication that the support may not be suited to play on certain equipment was misleading to the consumer in respect of the essential characteristics of the product. ${ }^{5}$ The District Court of Nanterre upheld a complaint introduced by the same association against Sony UK and Sony France on the ground that the former had failed to inform consumers about the lack of interoperability of their products and services to other devices. The court found Sony liable for misleading the consumers by "the fact that Sony did not explicitly and clearly inform the consumer that the music players sold could read only the music files downloaded on the only legal site Connect." "Sony UK was also held liable for failing to explicitly state in its contract that the music files downloaded from the Connect website could be read only by the music players dedicated for the Sony trademark (Guibault et al. 2007, p. 160). Both series of cases were

\footnotetext{
${ }^{2}$ Directive 2001/29/EC of the European Parliament and of the Council on the harmonisation of certain aspects of copyright and related rights in the information society, O.J.E.C. L 167, 22 June 2001, p. 10-19.

${ }^{3}$ The American concept of 'fair use', codified at section 107 of the U.S. Copyright Act of 1976, is an open defence to a copyright infringement action that is not recognized anywhere in Europe. The concept of 'fair dealing' admitted in the United Kingdom and Ireland is much narrower than its American counterpart, since it applies strictly to cases of research or private study, criticism or review, and news reporting.

${ }^{4}$ Court of Appeal of Paris, 4th chamber, section A, Decision of 20 June 2007 Fnac Paris / UFC Que Choisir et autres, <http://www.legalis.net/jurisprudence-decision.php3?id_article=1967>; TGI Paris, 10 January 2006, Christophe R et UFC Que Choisir v. Warner Music France et FNAC, <http://www.legalis.net/ jurisprudence-decision.php3?id_article=1567>; TGI Nanterre, 24 June 2003, Association CLCV/EMI Music France, $<w w w . l e g a l i s . n e t / c g i-i \overline{d d n} /$ french/affichejnet.cgi?droite= internet_dtauteur.htm $>$; Court of Appeal of Versailles, 30 September 2004, S.A. EMI Music France v. Association CLCV, <http://www.foruminternet. org/documents/ jurisprudence/lire.phtml?id=809>.

${ }^{5}$ Court of Appeal of Paris, 4th chamber, section A, Decision of 4th April 2007 UFC Que Choisir, Stéphane P. / Films Alain Sarde et autres, <http://www.legalis.net/jurisprudence-decision.php3? id article=1909>; TGI Nanterre, $15^{\mathrm{e}}$ chamber, 31 May 2007, Ministère Public, UFC Que Choisir, C.L.C.V. c/ SAS EMI Music France, <http://www.foruminternet.org/specialistes/veille-juridique/jurisprudence/IMG/pdf/tgi-nan20070531. pdf>.

${ }^{6}$ TGI Nanterre, 6e chamber, 15 Decembre 2006, Association UFC Que Choisir v. Société Sony France, Société Sony United Kingdom Ltd, <http://www.legalis.net/jurisprudence-decision.php3? id_article=1816>.
} 
won on the basis of article L. 213-1 of the French Consumer Code, which condemns any deceiving practice 'in respect of the nature, species, origin, material qualities, composition or content in terms of useful principles of any merchandise'.

Apart from France, Belgium ${ }^{7}$ is the only other Member State of the European Union where such disputes have reached the courts. The question therefore arises whether the current European consumer protection law offers European consumers comparable guarantees for transparency in their transactions with digital content providers. Three directives may find application, here: the Distance Contracts Directive, ${ }^{8}$ the Electronic Commerce Directive, ${ }^{9}$ and the Unfair Commercial Practices Directive. ${ }^{10}$ As explained below, the two first directives apply to both products and services, and more specifically to online contracting. Both Directives contain transparency provisions that oblige the supplier to give certain information to the consumer before the completion of the transaction. The third directive concerns all business-to-consumer practices, whether off-line or on-line.

The Distance Contract Directive requires that, before the contract is concluded, the consumer be given information on, amongst other things, the supplier's name (Article 4(1) (a)), the main characteristics of the goods or services (Article 4(1)(b)) and the total price (Article 4(1)(c)). For most products and services, the consumer has the right to withdraw from the transaction without penalty or justification (Article 6(1)). Arguably, the right of withdrawal also applies to click-wrap licenses that accompany goods and services on the Internet. However, article 6(3) of the Directive provides that, unless otherwise agreed to by the parties, the right of withdrawal is expressly removed with respect to contracts for the supply of audio or video recordings or computer software which were unsealed by the consumer, and for the supply of newspapers, periodicals and magazines.

The Electronic Commerce Directive's main purpose regarding the formation of contracts is to ensure that the legal system of each Member State allows contracts to be validly concluded by electronic means. To this end, service providers have an obligation to provide certain information prior to the conclusion of the contract. Moreover, contract terms and general conditions provided to the recipient must be made available in a way that allows her to store and reproduce them. The Electronic Commerce Directive requires that the following information be provided to the other contracting party before the conclusion of the transaction: the name and geographic and electronic address of the provider of the service (Article 5(1) (a)(b)(c)), a clear indication of the price (Article 5(2)), information on which codes of conduct apply and where to consult them electronically (Article 10(2)) and the obligation to make the contract terms and general conditions available in a way that allows the consumer to store and reproduce them (Article 10(3)) (Helberger and Guibault 2005 , p. ).

Modelled after the French provision in the Consumer Code, Article 6(1)(b) of the Unfair Commercial Practices Directive states that 'a commercial practice shall be regarded as

\footnotetext{
${ }^{7}$ Tribunal de première instance de Bruxelles, L'ASBL Association Belge des Consommateurs TestAchats/SE EMI Recorded Music Belgium, Sony Music Entertainment (Belgium), SA Universal Music, SA Bertelsmann Music Group Belgium, SA IFPI Belgium, decision of 25 May 2004, No 2004/46/A du rôle des référes;

${ }^{8}$ Directive 97/7/EC of the European Parliament and of the Council of 20 May 1997 on the Protection of Consumers in Respect of Distance Contracts, O.J.E.C., L 144, 4 June 1997, p. 19-27, art. 2.

${ }^{9}$ Directive 2000/31/EC of the European Parliament and of the Council of 8 June 2000 on certain legal aspects of information society services, in particular electronic commerce, in the Internal Market (Directive on electronic commerce), O.J.E.C. L 178, 17 July 2000, p. 1, art. 9 and ff.

${ }^{10}$ Directive 2005/29/EC of the European Parliament and of the Council of 11 May 2005 concerning unfair business-to-consumer commercial practices in the internal market, O.J.E.C. L 149, 11 June 2005, p. $22-39$.
} 
misleading if it contains false information and is therefore untruthful or in any way, including overall presentation, deceives or is likely to deceive the average consumer, even if the information is factually correct, in relation to one or more of the following elements, and in either case causes or is likely to cause him to take a transactional decision that he would not have taken otherwise: (b) the main characteristics of the product, such as its availability, benefits, risks, execution, composition, accessories, after-sale customer assistance and complaint handling, method and date of manufacture or provision, delivery, fitness for purpose, usage, quantity, specification (...)'.

From the above, one observes that both the Distance Contracts Directive and the Unfair Commercial Practices Directive refer to 'information on the main characteristics of the goods or services'. The first directive lays a positive obligation on the service provider to supply information, while the second directive puts a negative obligation to refrain from misleading consumers on the main characteristics of a good or a service. There is, however, no clear positive obligation to provide precise information on elements such as the playability of digital file on specific devices, on the compatibility between certain files and devices, on the possibility to port the files from one format to another, etc.

The question therefore is whether such elements of information constitute the main characteristics of the goods or services' about which providers must inform consumers pursuant to the Distance Contracts Directive. As the French courts have readily accepted, there are compelling arguments in support of the thesis that this type of information does form the main characteristic of a music CD, film DVD, or downloaded file (Helberger and Hugenholtz 2007, p. 1092). Moreover, the failure to inform consumers about the application on a digital support of an anti-copy device, which prevents them from making any copy for time- or place shifting purposes, could probably amount to a misleading practice that would be prohibited under the Unfair Commercial Practices Directive (Helberger and Guibault 2005, p. 15; Lucchi 2007, p. 67).

In the absence of a clear indication in the law, the decision on this point remains at the discretion of the national courts, with all the uncertainty that this may bring. This uncertainty manifests itself in practice by a plethora of solutions put forward by content manufacturers and service providers, ranging from a simple logo designed to indicate that the content is copy-protected, to a notice on or around the product listing the system requirements for proper use of the content purchased. Generally speaking, the amount of information currently conveyed by means of a logo or a notice is not sufficient to give consumers a clear and complete picture of what can and cannot be done with a particular content file or support, as shown in the French cases.

In light of the above, one can easily conclude that the obligations set out in the three directives do not fully meet the information needs of consumers of copyright material. Imposing a duty on rights owners to disclose relevant information regarding the TPMs applied to the support or to observe specific formalities at the time of the conclusion of the standard form contract would contribute to reducing inequalities between parties, insofar as it would compensate for the lack of information or experience on the part of the consumer. Should the supply of pre-contractual information fail to meet its objective and should consumers incur damages as a result of the use of files or devices, the provisions of the Directive on the sale of consumer goods and guarantees could perhaps be applied by analogy to e-goods, in order to provide consumers with some remedy. ${ }^{11}$ Nevertheless, such procedural requirements would not eliminate the risk that rights owners might abuse their

${ }^{11}$ Directive 1999/44/Ec Of The European Parliament And Of The Council of 25 May 1999 on certain aspects of the sale of consumer goods and associated guarantees 
economic and bargaining position by making systematic use of licence terms that are unfavourable to consumers (Guibault 2002, p. 252).

\section{Restrictive Terms of Use}

Increasingly, copyright works are put on the market subject to contractual terms of use. In fact, the deployment of DRM systems not only presupposes the application of technological protection measures to protected works, but it also entails the use of contractual agreements spelling out the acts that users are permitted to accomplish with respect to the licensed material. The contractual framework generally remains voluntary and market-driven, knowing that the principle of freedom of contract constitutes a cornerstone of European contract law. For example, with respect to the on-line distribution of music, the technology used by popular music download sites, such as those of Apple iTunes or On Demand Distribution Ltd. (OD2), typically allow consumers to make three transfers to a portable device, to burn one $\mathrm{CD}$ and play the downloaded music an unlimited number of times on a specific PC. Not all on-line content distributors are as accommodating to the consumers' expectations as these, however. It is not uncommon to find some electronic licences that contain restrictions on use that purport to take away the privileges that copyright law normally grants the user.

\section{Validity of Restrictive Licenses under Copyright Law}

Although the Information Society Directive ${ }^{12}$ does not regulate the issue of consumer contracts as such, it does create a legal framework within the boundaries of which rights owners are able to license their rights to consumers. This framework essentially consists of rules regarding the scope of protection of copyright and related rights, including limitations on rights, as well as TPM's, most of which are default rules that parties to an agreement are free to set aside. How does this framework influence the form and content of end-user licences used in the context of DRM systems? To what extent do these contractual arrangements take account of the interests of end-users? Are most contractual arrangements compatible with the general policy goals pursued by the Directive?

Since more and more works of all kinds are distributed to the mass-market under conditions set by contractual agreements, particularly in the on-line environment, one might have expected that, in light of this growing practice, the European legislator would address the issue of the relationship between the rules of copyright law and contract law and clarify the weight to be given to limitations on copyright. The Information Society Directive contains, however, very few provisions referring to the conclusion of contractual licences as a means to determine the conditions of use of copyright protected works.

Recital 53 and article 6(4) of the Directive both deal with the use of technological measures to ensure a secure environment for the provision of interactive on-demand services. Article 6(4) second paragraph provides that Member States "may also take such measures in respect of a beneficiary of an exception or limitation provided for in accordance with Article 5(2)(b), unless reproduction for private use has already been made possible by rightholders to the extent necessary to benefit from the exception or limitation concerned and in accordance with the provisions of Article 5(2)(b) and (5), without preventing rightholders from adopting adequate measures regarding the number of

${ }^{12}$ Directive 2001/29/EC of the European Parliament and of the Council on the harmonisation of certain aspects of copyright and related rights in the information society, O.J.E.C. L 167, 22 June 2001, p. 10-19. 
reproductions in accordance with these provisions." Member States are under no obligation to take action in respect to the private copying exception. Moreover, if the rights holder designs his TPM in such a way that private copies are possible, then Member States are not allowed to intervene on the basis of article 6(4). And, as the text of Recital 52 states, right holders may in any case use TPMs to control the number of reproductions in accordance with art. 5(2)(b) and art. 5(5). TPMs that are used to control the number of reproductions receive equal protection according to article 6(4) paragraph 3 (Dusollier 2005, p. 175).

However, the fourth paragraph of this same article takes away the obligation of rights owners and Member States to ensure that the beneficiaries of certain enumerated limitations are given the means to exercise such limitations in respect of works protected by a TPM, whenever such works are "made available to the public on agreed contractual terms in such a way that members of the public may access them from a place and at a time individually chosen by them". The term "agreed contractual terms" in this provision could be interpreted as requiring the negotiation of a licence of use. In practice, however, most contracts in the digital networked environment take the form of 'take-it-or-leave-it' licences, where users only have the choice of accepting or refusing the terms of the licence presented to them on the Internet. While this provision establishes a rule of precedence between the use of contractual arrangements and the application of technological protection measures, no rule has been established anywhere in the Directive concerning the priority between contractual arrangements and the exercise of limitations on rights.

While the initial intention of the European legislator appears to have been to encourage economic players to move towards a more finely tuned and individualized form of rights management, it is doubtful whether the legal framework actually put in place by the Directive is capable of catering for the interests of all parties involved, especially those of consumers. Besides restricting the possibility for consumers to make a private and non-commercial use of the protected material, end-user licences typically contain a prohibition to reproduce, copy, distribute, publicly communicate, transform or modify the content without prior written permission from the rights owner. Although the wording used in most licences does not specifically prohibit such acts as the use of a work for educational purposes, or for purposes of quotations, news reporting, parody, private study or research, a general prohibition on any kind of reproduction or communication to the public could be interpreted as such.

This wording seems to imply that protected works made available on these online services are accessed and used only by passive consumers, who limit themselves to reading, listening to, or viewing the downloaded material. This assumption, however, does not hold true in practice, where users are becoming more and more creative in the digital environment, as sites like YouTube, Facebook, DailyMotion and WikiPedia so aptly demonstrate. Restrictive contract terms may therefore impede such legitimate uses as music review, media studies and film critique, to name just a few examples (Stromdale 2006, p. 4). In order to be able to make any kind of legitimate use of a work, consumers should unequivocally be allowed to benefit from the limitations on rights recognised in copyright and related rights law.

\section{Validity of Restrictive Licences under Consumer Protection Law}

The provisions of the European Directive on Unfair Contract Terms ${ }^{13}$ cover mass-market licences for the use of copyright material, provided that the conditions of application are

${ }^{13}$ Council Directive 93/13/EEC of 5 April 1993 on unfair terms in consumer contracts, O.J.E.C. L 95, 21 April 1993, p. 29-34. 
met. A first condition is that the other party to such a licence is a 'consumer' as defined in the Directive, that is 'any natural person who, (...), is acting for purposes which are outside his trade, business or profession'. ${ }^{14}$ Second, the Directive provides that the assessment of the unfair nature of the terms must relate neither to the definition of the main subject matter of the contract nor to the adequacy of the price and remuneration for the goods and services rendered. However, the Directive gives no indication of what is to be considered as the 'main subject matter of a contract'. A licence term may be deemed essential if it is of such substantial significance that without them the contract would not have been formed or that there would be no proper manifestation of intention. Such essential terms are thus excluded from the definition of a 'general condition' included in a non-negotiated contract, thereby escaping judicial review. In the absence of any relevant court decision on the issue, it is still unclear whether a term that restricts the privileges normally granted to users under copyright law would be considered as pertaining to the main subject matter of the licence.

Assuming that the term under review does not touch on the essence of the performance, a term will be regarded as unfair under the Directive if, contrary to the requirement of good faith, it causes a significant imbalance in the parties' rights and obligations arising under the contract to the detriment of the consumer (Helberger and Hugenholtz 2007, p. 1090; Lucchi 2007, p. 61). The list in the annex to the Directive is meant to give an indication of the clauses that may be regarded as unfair. The only clause appearing in the list that could apply in the context of a licence for the use of copyright material, is the one that 'irrevocably bind[s] the consumer to terms with which he had no real opportunity of becoming acquainted before the conclusion of the contract'. This type of clause relates more to the formation of the contract and the accuracy of the consumer's assent to the obligations contained therein, than to the fairness of the contractual obligations themselves. As a result, consumers must turn to the open norm laid down in the Directive and in national private law. This principle may be invoked every time that the specific provisions on unfair terms cannot be applied, because the term has been negotiated or because the term under review relates to the main subject matter of the contract. Under both types of provisions, the fairness of a term is assessed by referring, at the moment of the conclusion of the contract, to all the circumstances that surround its conclusion, to the mutually apparent interests of the parties, to the common usage of the trade, as well as to all other clauses of the contract (Guibault 2002, p. 255). ${ }^{15}$

A term included in a standard form contract is generally regarded as unfair if, contrary to the requirement of good faith, it causes a significant imbalance in the parties' rights and obligations arising under the contract to the detriment of the other party. In order to determine whether a licence term that prevents the use of public domain material or that purports to restrict the privileges for users normally recognised under the copyright act is unreasonable or abusive, courts would have to consider all the circumstances that prevailed at the time of conclusion of the contract. Admittedly, the outcome of this type of inquiry may vary significantly from one country to another. Furthermore, the court may come to a different conclusion depending on whether the contested clause relates to restrict the exercise of a limitation on copyright or the use of public domain material. Unfortunately, no relevant case law is available to offer any guidance at this time (Helberger and Hugenholtz 2007, p. 1090).

\footnotetext{
${ }^{14}$ Directive on Unfair Terms, art. 2(b).

${ }^{15}$ French Consumer Code, art. L 132-1 5th par.; Dutch Civil Code, art. 3:12, 6:233a); BGB, § 157 and German Civil Code, art. 310(3)(3).
} 


\section{Preserving the Balance of Interests}

The widespread use of restrictive standard form contracts in the online environment poses a threat to some of the basic objectives of copyright policy. If technological measures are prone to undermine essential user freedoms, the same is true a fortiori for standard form licenses. In fact, the use of DRM systems in combination with on-line standard form contracts may accentuate information asymmetries, indirect network effects, high switching costs and lock-ins, leading to market failures and thereby preventing well-functioning competition (Bechtold 2004, p. 362). Absent certain limits to freedom of contract, lawful consumers may be forced to forego some of the privileges recognised by law, in order to be able to use protected material. This practice in effect tilts the balance of interests far in favour of rights owners to the detriment of consumers.

In order to restore the balance of interests between rights owners and lawful end-users, the relationship between the protection by copyright law, TPMs, and contract needs to be re-assessed. What would be the most appropriate measure to achieve the objective of restoring the balance of interests? In which body of law would such a measure best be integrated: copyright law, contract law, or consumer law? In the following pages, we discuss the advantages and drawbacks of some of the options available to the European legislator to limit the freedom of contract in order to preserve the balance of interests between rights owners and content providers on the one hand, and lawful consumers of protected material, on the other hand. These options vary between adopting a rule in consumer protection law; regulating standard form contracts in private law; declaring limitations on copyright imperative; and promoting the development and acceptance of codes of best practice. Note that some of the solutions proposed here are better suited to address the problems raised by unfair license terms than by a lack of pre-contractual information.

\section{Consumer Protection Rule}

As copyright works are increasingly being distributed on the mass market subject to the terms of standard form contracts, consumers of protected material are likely to be confronted more and more with contract clauses that attempt to restrict the privileges normally granted to them under copyright law. The consumer's only choice is often to refuse to transact under the conditions set out in the standard form contract. In view of the users' inferior bargaining power and information asymmetry, the question is whether and to what extent the introduction of a rule in consumer protection law could improve the user's position with respect to such restrictive contract clauses. Consumer protection rules typically purport to operate on two levels: first, to increase the consumer's pre-contractual information and, second, to offer protection against unreasonable one-sided contract terms. Community legislative intervention could be envisaged on both levels, namely imposing an obligation to inform consumers of the licensing conditions before they proceed to a purchase, and regulating the content of the licences.

Imposing a duty on rights owners to disclose particular information or to observe specific formalities at the time of the conclusion of the standard form contract does contribute to reducing inequalities between parties, insofar as it increases transparency and compensates for the lack of information or experience on the part of the end-user. While they were absolutely unknown to the area of copyright just a few years ago, consumer protection measures related to copyright matters have recently become more frequent. This is the case for example of article 95d) of the German Copyright Act, which as a result of the implementation of the Information Society Directive, now requires that all goods protected 
by technological measures be marked with clearly visible information about the properties of the technological measures.

However, the obligation to supply information imposed by the German law or by the French courts has so far addressed only the restrictions put by technology and not the restrictions imposed inside contractual agreements. These rules do not eliminate the risk that rights owners abuse their economic and bargaining position by making systematic use of licence terms that are unfavourable to consumers (Guibault 2002, p. 251). Since, in practice, pre-contractual information regarding restrictive terms of use of copyright material would only have limited effect on the consumers' situation, another type of intervention may be called for. One possibility could be to extend the regulations concerning unfair consumer contract terms to cover copyright matters.

The Community legislator could introduce an item in the list of unfair clauses, according to which a term in a non-negotiated contract would be deemed unfair if it departed from the provisions of the copyright act. This provision could be incorporated into the 'black' list of contractual clauses, e.g. those that are deemed unfair under consumer protection law and where the presumption cannot be rebutted. Such a presumption of unfairness would have the advantage of having a broad application, relating not only to limitations on copyright, but also to any other provisions of the copyright act, such as those concerning the term of protection. One inconvenient with this option would be, however, that it could undermine new, potentially attractive business models or deter the industry from making content available online at all. As Helberger and Hugenholtz point out, 'an absolute ban on contractual clauses that prohibit private copying would result in less choice for the consumers' (Helberger and Hugenholtz 2007, p. 1095).

\section{Regulating Contractual Agreements}

To make sure that not only consumers but all types of end-users of copyright material, be they professionals, public libraries, archives and educational institutions, benefit from a protective measure against the use of restrictive terms in standard-form contracts, a second option could be to introduce a provision in the general contract law of the Member States. The contract law in most Member States regulates a number of specific contracts, like lease, sale, insurance, and labour contracts. Like the consumer protection rules, the rules governing these specific categories of contracts purport to ensure the proper functioning of the pre-contractual phase, to regulate their content, and to impose formalities where necessary. Member States could be encouraged to introduce a section in their national contract law on the subject of copyright licences. A rule of contract law could be adopted to declare any clause in a non-negotiated licence null and void which, contrary to the requirement of good faith, causes a significant imbalance in the parties' rights and obligations arising under the contract to the detriment of the other party. Alternatively, the rule could simply dictate that any contractual clause in a standard-form contract is deemed unfair if it departs from the provisions of the national copyright act.

The main problem with this option is that contract law is a matter generally not considered as falling under the competence of the European Union. Although some efforts have been deployed over the past decade to approximate the laws of the Member States in the field of contract law, the European Community has so far been only indirectly involved in the process. ${ }^{16}$ To date, the initiative has been limited to rationalising and tidying up the

\footnotetext{
${ }^{16}$ European Parliament, Committee on Legal Affairs and the Internal Market, European Parliament resolution on European contract law and the revision of the acquis: the way forward (2005/2022(INI)), Brussels, 23 March 2006.
} 
acquis in the field of consumer protection and to producing optional standard contract terms and conditions. This situation renders the adoption by the European Community of a new rule on contract law regulating copyright licences rather unlikely. Moreover, since the basic rules on contract law must still be officially harmonised across the Member States, the creation of such a specific set of rules on copyright licences may not be called for at this time.

\section{Declaring Copyright Limitations Imperative}

A third option to restore the balance of interests inside online contractual agreements would be to declare some or all limitations on copyright and related rights imperative (Gasser 2006, p. 111). European copyright law recognizes very few imperative limitations. These flow from the Computer Programs Directive and the Database Directive. According to a provision in the two Directives, any contractual provision contrary to the provisions laying down these limitations is null and void. The Information Society Directive contains no imperative limitation on copyright. By contrast, some limitations in the Information Society Directive are expressly default rules, like article 5(3)n), which makes libraries and their patrons dependent on the benevolence of the rights holders. As a result, the vast majority of limitations on copyright in the acquis communautaire have been declared neither expressly mandatory nor optional. In view of the silence of the Information Society Directive and a general lack of relevant case law in the Member States, the status of the limitations listed in article 5 remains unclear. Even the status inside contractual relations of the mandatory provision of article 5(1) of the Directive has yet to be clarified (Guibault et al. 2007, p.162).

Interestingly, two Member States, Belgium and Portugal, have actually dealt with the issue in their national copyright laws. In its Act of 1998 implementing the Database Directive, Belgium not only declared imperative every mandatory and optional limitation relating to databases, but it also proclaimed the imperative character of most other limitations included in the Copyright Act. ${ }^{17}$ According to Article 23 bis of the Act, Articles $21,22,22$ bis and $23, \S \S 1 \mathrm{er}$ and 3 have a mandatory character. Unfortunately since its enactment, Article 23bis of the Belgian Copyright Act did not give rise to any case law, although a few good occasions to test it might have been overlooked. However, with the implementation of the Information Society Directive, and particularly of its article 6(4), fourth paragraph, the Belgian legislator appears to have made one major step backwards in this matter. A second sentence was indeed added to the original text of article 23 bis of the Act, which now reads as follows:

"The provisions of articles 21, 22, 22bis and 23, $\S \S 1 \mathrm{er}$ and 3 have a mandatory character. It is, however, possible to deviate from these provisions on a contractual basis in relation to works made available to the public on agreed contractual terms in such a way that members of the public may access them from a place and at a time individually chosen by them".

This amendment is probably the result of an erroneous interpretation of the intention of the European legislator. The Belgian legislator must have confused, in Article 6(4), fourth paragraph of the Directive, the absence of obligation to provide the means to benefit from a limitation in cases where the work is made available online according to the terms of a contract, with the possibility to contract around the limitations. The first measure has in fact

${ }^{17}$ Belgian Copyright Act of 1994, as modified, art. 23 bis. 
little to do with the second. If a rights holder does not have to provide the means to exercise a limitation, either by providing a decryption key or a TPM-free version of the work, this does not imply that rights holders should be free to contract out of the privileges granted by the law. In any case, all this leads to an odd result. While the Belgian legislator recognises the importance of protecting the beneficiaries of limitations on copyright in their off-line contractual relations, it leaves basically intact the freedom of contract in online relationships, where the need for protection of users is much more pressing. Consequently, the Belgian law is probably doomed to remain a dead letter (Janssens 2005, p. 509).

The provision of the Portuguese Copyright Act is more convincing and probably much more effective than its Belgian counterpart. Article 75(5) of the Portuguese Act No. 50/ 2004 declares void any unilateral contractual provision eliminating or impeding the normal exercise of the free uses mentioned in the Act. As the wording indicates, this provision applies with respect to all limitations recognised in the Portuguese Copyright Act. This legislative modification occurred during the implementation of the Information Society Directive, and is premised on the observation that often the unequal bargaining power of the parties will mean that only one of them will be able to determine the terms of a contract to the possible detriment of the other party. As Akester points out, although it does not expressly say so, this provision is meant to avoid unilateral decisions as regards exceptions and limitations (Akester 2005, p. 10). But the Portuguese legislator showed more consistency in its policy decisions, when implementing article 6(4), fourth paragraph of the Information Society Directive. Article 222 of the Portuguese Copyright Act provides as follows:

"This scheme does not apply to copyright works made available to the public on agreed contractual terms, in such a way that members of the public may access them from a place and at a time individually chosen by them."

The two Portuguese provisions precisely fill the gap left by the Information Society Directive. They ensure that, while rights owners are under no obligation to provide the means to exercise certain limitations with respect to a work that is protected by a TPM and made available online on agreed contractual terms, they may not eliminate or impede the normal exercise of the free uses mentioned in the Act on the basis of these "agreed contractual terms." In other words, rights owners may protect their works by TPMs, but they may not contractually prohibit users from exercising a limitation.

While the copyright laws of the other Member States do not expressly recognise the imperative character of limitations on copyright, the view that limitations form an integral part of the balance of interests established by the copyright system, from which contracting parties can not derogate by way of standard-form licenses, is slowly gaining acceptance throughout the European Union. While this position is generally well-admitted in countries following the common law tradition, a change of perception in this direction is noticeable in a number of countries following the droit d'auteur tradition (Lucas 2006, p. 309). The same remark also applies, of course, to the weight given to limitations on copyright, including the fair dealing doctrine, under the British and Irish copyright acts. Therefore, the express recognition of the imperative character of statutory limitations may not encounter as much resistance on the part of European lawmakers as one might have initially feared.

Should the European legislator decide to declare limitations on copyright imperative in contractual relations, two issues should still be addressed: first, whether all limitations recognised in Community copyright law should be declared mandatory; and second, whether such a declaration should apply to all types of contracts, irrespective of whether they are the result of a negotiation process or not. 
With respect to the first question, the argument has often been made in the legal commentaries that while limitations represent the legislator's acknowledgment of the users' legitimate interests, not all of these interests should be given the same weight (Janssens 2005, p. 510; De Werra 2003 at p. 330). Since quite a number of limitations included in the Information Society Directive would probably qualify as "minor reservations", there would be no justification to grant these limitations an imperative character. On the other hand, the European legislator could consider recognising the imperative character of the limitations that reflect the users' fundamental rights and freedoms enshrined in the ECHR, as well as those that have a noticeable impact on the Internal Market or concern the rights of European consumers. This proposal could be without prejudice to article 6(4), fourth paragraph, of the Information Society Directive, which could remain unaffected. However, such a regime would safeguard the integrity of the European legislator's policy goals with respect to the users' interest. For, if the legislator has deemed it appropriate to limit the scope of copyright protection to take account of the public interest, there would be no reason in principle why private parties should be allowed to derogate one way or another from the legislator's intent (Guibault et al. 2007, p.164).

Concerning the second question of whether the imperative character of the limitations on copyright should be made opposable to all types of contracts, the risk of such a broad rule would be that it might frustrate the negotiation and conclusion of valuable contracts (Guibault 2002, p. 194). The principle of freedom of contract and party autonomy should prevail wherever it does not conflict with public policy or public order. When a licensor and a licensee negotiate with a view to concluding a bargain, they usually understand the nature of their respective rights and obligations, including those rights that the licensee agrees to forego. In principle, neither party would enter the agreement if the bargain were not favourable to each of them in the circumstances. On the other hand, the widespread use of standard form contracts has the potential severely to upset the traditional balance established by copyright law and of standing as an obstacle to the accomplishment of the full purposes and objectives of the legislator's public policy. These contracts typically attempt to redefine the boundaries of the copyright protection. Consequently, limitations should be declared imperative only with respect to standard form contracts. This proposal would not only coincide with Portugal's solution, but also with the position adopted by the courts in Denmark, where judges have ruled that limitations cannot be unilaterally contracted out of by way of imposing restrictive terms and conditions (Guibault et al. 2007, p.165).

\section{Promoting the Adoption of Codes of Conduct}

As a last possible option, which could be combined with the previous options, Member States might encourage industry players to develop codes of conduct, which would address concerns regarding transparency and fairness of contractual terms. Self-regulation of the private sector could be more efficient, better fit the electronic environment, and reduce rulemaking and enforcement costs. Indeed, a rule that is developed in concert between parties concerned has generally much more chance of being respected than a rule imposed by the legislator. The parties concerned, including rights owners, information service providers, and consumers, could reach an agreement on the pre-contractual information required in relation to the technical features of the products and services, the compatibility and the playability of files and devices etc. An additional aspect of this self-regulatory mechanism could deal with the issue of on-line contracting on copyrighted material, and might codify certain imperative user freedoms (Helberger and Hugenholtz 2007, p. 1095). If the parties 
concerned were able to agree on the type of acceptable and fair clauses inside the standard form contracts used for the distribution and making available online of copyright protected material, it would reduce the need to introduce a legislative measure to the same effect.

\section{Conclusion}

Although the major record labels are currently pulling back from the application of TPMs on their works, no one knows what the future holds. Circumstances may occur where rights owners see an advantage in re-applying TPMs for the distribution of their works online or off-line. It is therefore not excluded that consumers keep encountering technical difficulties with respect to the compatibility and playability of files and devices. As this article has shown, however, the current European legal framework is not tailored to meet the consumer's transparency needs, for the obligations put by the existing directives on information service provider to supply pre-contractual information do not cover the necessary information.

Since the rules of European consumer protection law are unclear concerning the extent of the service provider's obligation to inform consumers on the main characteristics of a digital entertainment product, a clarification in this sense would be called for. This could be achieved either in the general framework of consumer protection law or within the copyright act, following the German model. In the alternative, stakeholders could also develop codes of conduct to specify which pre-contractual information should be provided and in which form.

The tendency to market works to the general public subject to the terms of a licence of use is not diminishing, despite the decision regarding the application of TPMs. Consumers are emerging as the weaker party in the transaction. One option to restore the balance of interests inside online contractual agreements would be to declare some or all limitations on copyright and related rights imperative. So far, only Portugal has adopted a measure to prevent the use of standard form contracts excluding the exercise of limitations on copyright to the detriment of the user. In view of the potential chilling effect that such restrictive licences may have on the consumer's actions, it may be desirable to adopt a rule protecting his interests. Several options were presented in this paper that could provide a basis for a legislative action. In my opinion, the most efficient measure would be to introduce inside the copyright act, a provision according to which any unilateral contractual provision eliminating or impeding the normal exercise of the limitations recognised by law is null and void.

Open Access This article is distributed under the terms of the Creative Commons Attribution Noncommercial License which permits any noncommercial use, distribution, and reproduction in any medium, provided the original author(s) and source are credited.

\section{References}

Akester, P. (2005). Implementation of the information society directive in Portugal. Entertainment Law Review, 16, 7-12.

Bechtold, S. (2004). Digital rights management in the United States and Europe. American Journal of Comparative Law, 52, 323-382.

De Werra, J. (2003). Moving beyond the conflict between freedom of contract and copyright policies: in search of a new global policy for on-line information licensing transactions. Columbia Journal of Law and the Arts, 25, 239-375. 
Dusollier, S. (2005). Droit d'auteur et protection des oeuvres dans l'univers numérique: droits et exceptions à la lumière des dispositifs de verrouillage des œuvres. Brussels: Larcier.

Gasser, U. (2006). Legal frameworks and technological protection of digital content: moving forward towards a best practice model. Fordham Intellectual Property, Media and Entertainment Law Journal, 17, 39-113.

Guibault, L. M. C. R. (2002). Copyright limitations and contracts: An analysis of the contractual overridability of limitations on copyright. The Hague: Kluwer Law International.

Guibault, L., Westkamp, G., Rieber-Mohn, T., et al. (2007). Study on the Implementation and Effect in Member States' laws of Directive 2001/29/EC on the Harmonisation of Certain Aspects of Copyright and Related Rights in the Information Society, report to the European Commission, DG Internal Market, http://www.ivir.nl/publications/guibault/Infosoc_report_2007.pdf.

Helberger, N. (2005). Digital rights management from a consumer's perspective. IRIS Plus, 8.

Helberger, N., \& Guibault, L. (2005). Consumer protection and Copyright Law, report prepared for the Bureau européen des Unions de Consommateurs, Brussels, http:/www.ivir.nl/publications/other/copy rightlawconsumerprotection.pdf.

Helberger, N., \& Hugenholtz, P. B. (2007). No place like home for making a copy: private copying in european copyright law and consumer Law. Berkeley Technology Law Journal, Available at SSRN: http://ssrn.com/abstract=1012305.

Janssens, M.-C. (2005). De uitzonderingen op het auteursrecht anno 2005-Een eerste analyse. Auteurs \& Media (6), 482-511.

Lucas, A. (2006). Chroniques-Droit d'auteur et droits voisins. Propriétés intellectuelles, 20, 297-316, p. 309.

Lucchi, N. (2007). Countering the unfair play of DRM technologies. Texas Intellectual Property Law Journal, 16 (1), Available at SSRN: http://ssrn.com/abstract=970995.

Stromdale, C. (2006). The problems with DRM. Entertainment Law Review, 17, 1-6. 